\title{
Perancangan Pembatas Interaksi sebagai Penunjang Kegiatan Bertransaksi di Kasir pada Masa New Normal
}

\author{
Andrianto $^{1}$ | Chris Chalik ${ }^{1}$ \\ ${ }^{1}$ Program Studi Desain Produk, Fakultas Industri Kreatif, Universitas Telkom, Bandung, Jawa Barat, \\ Indonesia \\ Corresponding author: Email : andriantoandri@telkomuniversity.ac.id
}

\begin{abstract}
ABSTRAK
Kondisi masyarakat saat ini sedang dihadapkan pada wabah pandemi yang bisa saja terpapar dari kegiatan interaksi antara manusia satu dengan lainnya, salah satunya adalah bertransaksi di kasir. Adanya keperluan untuk bertransaksi sulit untuk dihindari sehingga dibutuhkan sebuah perancangan yang dapat meminimalkan penyebaran virus sekaligus menimbulkan rasa aman dan nyaman para penggunanya saat melakukan kegiatan tersebut. Pembatas interaksi merupakan partisi atau sekat yang dapat membatasi kegiatan interaksi antara sisi satu dan lainnya yang dapat menjadi solusi atas permasalahan tersebut. Penelitian ini menggunakan metode kualitatif untuk mengetahui dan menganalisis kebutuhan pengunjung saat bertransaksi di masa pandemi, dimulai dengan melakukan wawancara dan observasi terhadap pengguna saat melakukan kegiatan transaksi di kasir sebagai data awal dan untuk merumuskan permasalahan, kemudian dikembangkan berdasarkan teori terkait warna, bentuk, dan material sesuai kebutuhan desain yang ada. Hasil perancangan berupa pembatas interaksi fungsional yang menekankan pada aspek bentuk dan warna disesuaikan dengan kebutuhan kegiatan bertransaksi pada fasilitas kasir untuk membantu pengguna agar tetap sehat terbebas dari risiko terpapar kuman dan virus. Hasil perancangan ini juga diharapkan dapat menjadi acuan penelitian maupun rujukan perancangan dengan tema serupa dalam rangka meminimalkan penyebaran virus di masa pandemi dan masa new normal.
\end{abstract}

\section{Kata Kunci: Desain, New Normal, Pandemi, Partisi, Transaksi}

\begin{abstract}
The current condition of the community is being faced with a pandemic outbreak which could be exposed to interaction activities between one human and another, one of them is transacting at the cashier. The need for transactions is difficult to avoid, so a design is needed that can minimize the spread of the virus while creating a sense of security and comfort for its users when carrying out these activities. The interaction barrier is a partition or divider that can limit one side to another which can be a solution to this problem. Using qualitative methods to identify and analyze visitor needs when transacting during the pandemic, this design begins with conducting interviews and observations of users when carrying out transactions at the cashier as initial data to formulate problems which are then developed based on theories related to color, shape and materials to analyze existing design needs. The design result is a functional interaction barrier which emphasizes the aspects of shape and color according to the needs of transaction activities at the cashier facility to help users stay healthy, free from the risk of being exposed to germs and viruses. The results of this design are also expected to be a reference for a study as well as a design reference with a similar theme in order to minimize the spread of the virus during the pandemic and the new normal period.
\end{abstract}

Keywords: Design, New Norm, Pandemic, Partition, Transaction

\section{PENDAHULUAN}

Pandemi Covid-19 yang terjadi di Indonesia sudah menyebar dengan sangat cepat ke beberapa wilayah. Pandemi ini berimbas pada terbatasnya berbagai kegiatan yang biasa dilakukan oleh masyarakat, seperti melakukan transaksi dalam kegiatan berbelanja atau kegiatan lainnya. Kegiatan bertransaksi merupakan kegiatan yang dilakukan antara penjual dan pembeli di suatu tempat. Menurut Gill and Shah (2012), motif bertransaksi merupakan penggunaan uang untuk transaksi sehari-hari dalam pemenuhan kebutuhan berupa barang atau jasa serta untuk melakukan pembayaran rutin. Berdasarkan penjelasan tersebut, dapat dilihat bahwa kegiatan transaksi dalam pemenuhan kebutuhan sehari-hari manusia tidak dapat dihindari, di sisi lain berbagai upaya sedang dilakukan untuk dapat menekan sekaligus mencegah penyebaran virus melalui kebijakan social distancing. Menurut Yusup (2020), social distancing adalah pembatasan jarak social 
dengan menciptakan jarak dengan orang lain sejauh 1-2 meter saat berinteraksi untuk mencegah penularan penyakit tertentu. Hal ini dilakukan mengingat penyebaran virus dari pandemi ini sangat cepat penularannya, namun kebijakan ini berimbas terhadap kegiatan transaksi itu sendiri bahwa kegiatan transaksi biasanya dilakukan dengan jarak yang cukup dekat antara penjual dan pembeli. Untuk itu dibutuhkan sebuah produk rancangan yang dapat menjadi solusi atas permasalahan tersebut. Menurut Laurens (2005), desainer yang baik adalah desainer yang dapat mengartikulasikan kebutuhan manusia pada setiap situasi tertentu melalui perancangan yang dapat memenuhi kebutuhan manusia. Berdasarkan keadaan pandemic yang terjadi saat ini, maka dibutuhkan sebuah perancangan yang dapat meminimalkan penyebaran virus sekaligus menimbulkan rasa aman dan nyaman para pengguna ketika melakukan kegiatan bertransaksi walaupun berada dalam jarak yang tidak ideal.

\section{METODE PENELITIAN}

Metode yang digunakan adalah metode penelitian kualitatif yakni studi kasus. Metode ini digunakan untuk mengeksplorasi secara mendalam mengenai aktivitas bertransaksi di masa pandemi. Dalam perancangan pembatas interaksi ini dilakukan penelitian dengan pendekatan metode kualitatif dalam upaya memahami kebutuhan pengguna terkait aktivitas transaksi di masa new normal. Dimulai dengan melakukan wawancara terhadap pemilik toko terkait kebijakan mereka dalam menerapkan protokol kesehatan dan juga para pengguna terkait pendapat mereka dalam melakukan protokol kesehatan tersebut. Data berikutnya didapatkan dari hasil observasi di beberapa minimarket dan retail store di sekitar Kota Bandung untuk mengamati perilaku pengguna, baik kasir maupun konsumen saat melakukan kegiatan transaksi di masa pandemi. Data yang didapatkan kemudian digunakan untuk mengetahui permasalahan guna menganalisis kebutuhan desain yang ada untuk dijadikan dasar objek perancangan.

Produk penunjang kegiatan dirancang untuk membentuk suatu kegiatan agar sesuai dengan kebutuhan manusia. Menurut Motloch (1991), aspek visual pada sebuah desain merupakan hal yang penting untuk menarik perhatian, untuk itu dalam rangka menarik perhatian pengunjung akan peningkatan kewaspadaan ketika harus menjaga protokol kesehatan dalam melakukan kegiatan bertransaksi, maka perancangan pembatas interaksi ini mengacu pada aspek visual tersebut. Menurut Sunaryo (2002: 6), aspek visual terdiri dari garis, bangun, warna, gelap terang, tekstur, dan ruang, dengan unsur desain paling dominan adalah bentuk dan warna yang akan diaplikasikan pada perancangan pembatas interaksi ini. Selain bentuk dan warna, aspek material menjadi pertimbangan yang cukup penting dalam perancangan pembatas interaksi ini, keterbatasan dan kebijakan yang ada di saat pandemi membuat terbatasnya akses dalam menggunakan material tertentu. Hal ini sesuai dengan yang diutarakan oleh Palgunadi (2008) bahwa dalam perencanaan suatu produk bahan yang digunakan harus mudah didapat. Walaupun bahan yang direncanakan sudah cukup baik tetapi tidak didukung oleh persediaan di pasaran, maka perencanaan akan mengalami kesulitan atau masalah di kemudian hari karena hambatan bahan baku tersebut.

\section{PEMBAHASAN}

Berdasarkan hasil wawancara dan observasi terkait aktivitas bertransaksi di kasir selama masa pandemi didapatkan hasil bahwa secara umum belum ada tindakan preventif, baik dari sisi pengelola maupun pengguna, protokol kesehatan yang diterapkan hanya penggunaan cairan disinfektan, pembatas jarak, dan pembatasan jumlah pengunjung yang datang. Adapun yang dilakukan untuk membatasi interaksi di area kasir hanya sebatas menggunakan mika sederhana yang berimbas pada ketidaknyamanan si pengguna, baik dari sisi visual maupun kemudahan dalam transaksinya itu sendiri. Oleh sebab itu, dibutuhkan sebuah perancangan yang ideal untuk dapat memfasilitasi kebutuhan interaksi yang nyaman di kasir tanpa mengurangi kewaspadaan mereka terhadap protokol kesehatan yang ada. Dalam setiap perancangannya, desainer dituntut untuk dapat mengenal target pengguna dari perancangannya tersebut, berdasarkan fungsinya pembatas interaksi ini adalah sebuah partisi transparan yang membuat batasan interaksi antara sisi satu dan sisi lainnya untuk mengurangi kontak fisik langsung di area kasir. Pembatas interaksi ini bisa digunakan pada segala macam kemungkinan interaksi dua sisi, yang memungkinkan manusia untuk tetap dapat merasa aman dan nyaman ketika melakukan kegiatan transaksi tersebut (gambar 1).

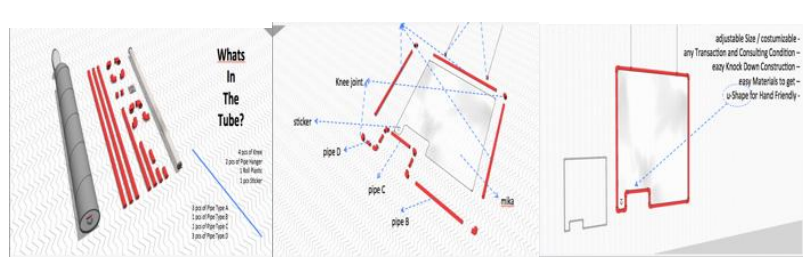

Gambar 1. Pembatas Interaksi 
Berdasarkan Wibowo (1999), pengembangan sebuah produk dibutuhkan agar perancangan sesuai dengan yang dirumuskan dalam permasalahan. Dalam perancangan pembatas interaksi ini menganalisis aspek visual yaitu bentuk dan warna serta aspek material yang dianggap membantu mengolah hasil perancangan. Berdasarkan aspek bentuk, perancangan pembatas interaksi ini menggunakan bentuk geometris kotak sederhana dengan fungsinya yang dianggap cukup untuk membatasi kegiatan transaksi tersebut. Menurut Palgunadi (2008), bentuk geometris memiliki sifat mudah terukur, sistematis, kaku, dan statis. Bentuk-bentuk geometris memiliki sifat yang mudah dikenali serta mudah diukur sehingga memudahkan pengguna untuk mengenali dan mengartikan sebuah objek agar tetap waspada terhadap protokol kesehatan. Oleh karena itu, bentuk geometris kotak sederhana dianggap paling tepat penggunaannya dalam perancangan pembatas interaksi ini. Menurut Radwan \& Morsy (2016), bentuk mendefinisikan material, ukuran, dan fungsi, dengan bentuk sebuah benda berawal dari fungsi yang mengidentifikasikan benda tersebut dan fungsi yang dibutuhkan dari benda tersebut. Untuk itu secara operasional pembatas interaksi ini dapat menyesuaikan ukuran dengan kondisi lapangan, mempunyai pilihan menggunakan penyangga untuk disimpan di meja atau menggunakan hanger untuk bisa digantung di langit-langit. Sistem dibuat knock down agar mudah dipindahkan dan dibawa ke mana saja, selain itu dengan menggunakan sistem ini dapat membuat pengemasan jauh lebih kecil dan mudah untuk didistribusikan. Sedangkan dari aspek warna, pembatas interaksi ini mempertimbangkan kebutuhan psikologis pengguna saat menggunakan produk ini, dengan aplikasi warna dalam desain dapat memberi suasana dan mempengaruhi mood seseorang. Menurut Sanyoto (2005), warna secara fisik adalah sebuah sifat dari cahaya yang dipancarkan, sedangkan secara psikologis sebagai bagian dari pengalaman indera dalam penglihatan. Menurut Budiarti (2012), warna merah secara umum dianggap warna terkuat dan paling menarik perhatian. Dalam kasus pembatas interaksi ini, warna merah dianggap menjadi penanda bahwa pengguna akan menjadi lebih waspada ketika melakukan kegiatan transaksi. Oleh karena itu, warna merah diaplikasikan pada rangka utama pembatas partisi (gambar 2).

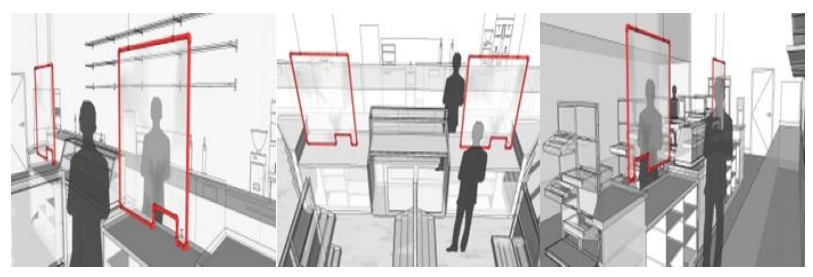

Gambar 2. Visualisasi Produk
Selain bentuk dan warna, menurut Putra \& Nazhar (2020), unsur materialpun dapat dipadukan dengan unsur warna dan atau bentuk. Pemilihan material dapat disesuaikan dengan fungsi dan kebutuhan yang diperlukan, oleh sebab itu penggunaan material sangat mempengaruhi perancangan sebuah produk. Menurut Mulyadi (2000), pengertian material adalah bahan baku yang diolah perusahaan industri dapat diperoleh dari pembelian lokal, impor atau pengolahan yang dilakukan sendiri. Pada perancangan pembatas interaksi ini, digunakan material yang mudah ditemui di pasaran mengingat selama masa pandemi terdapat keterbatasan distribusi untuk material-material tertentu. Menurut Rapoport (1969), material memfasilitasi dan membuat mungkin atau tidak mungkin keputusan desain tertentu, tetapi tidak pernah memutuskan atau menentukan bentuk. Sesuai fungsi yang memungkinkan untuk dibongkar pasang secara mudah, material pertama yang digunakan dalam perancangan pembatas interaksi ini adalah pipa PVC sebagai rangka utama, pipa ini dipilih mengingat material ini masih mudah ditemukan di pasaran dalam kondisi pandemi, selain itu terdapat pula knee joint yang memungkinkan untuk dapat dibongkar pasang dengan mudah tanpa menggunakan bantuan perekat. Ukuran pipa PVC yang dipilih adalah pipa dengan ukuran $3 / 4$ inci sehingga cukup kuat dan kokoh ketika digunakan dalam posisi menggantung di langit-langit. Menurut Palgunadi (2008), dalam sebuah perancangan bahan yang akan digunakan harus sesuai dengan fungsi yang berbeda antara bagian satu dengan bagian lain, dengan fungsi dari masing-masing bagian tersebut saling mempengaruhi antara bagian satu dengan bagian lainnya. Material kedua yang digunakan adalah mika rigid dengan ukuran 0,3 milimeter sebagai pembatas utama. Material ini dipilih karena mempunyai visualisasi transparan yang memudahkan pengguna untuk tetap dapat berinteraksi walaupun secara fisik terhalangi. Material terakhir yang digunakan dalam perancangan pembatas interaksi ini adalah velcro sebagai penyambung antara komponen mika dan komponen rangka utama yaitu pipa PVC. Agar perancangan efektif dan efisien, aspek produksi material penting menjadi pertimbangan agar produk yang dirancang mampu menyesuaikan dengan kondisi yang ada sesuai dengan metode yang sudah ditentukan sebelumnya. Dalam proses produksi perancangan pembatas interaksi ini dijelaskan sebagai berikut:

- Mempersiapkan alat dan material yang dibutuhkan.

- Membuat rangka utama dengan memotong pipa PVC sesuai dengan ukuran yang dibutuhkan (gambar 3). 


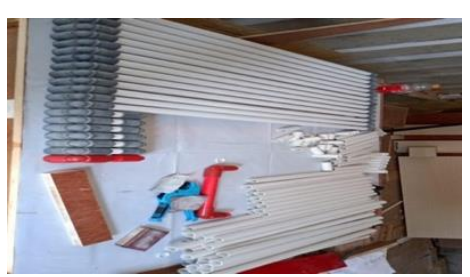

Gambar 3. Pemotongan pipa PVC

- $\quad$ Membersihkan permukaan pipa PVC untuk kemudian diberi cat dasar lalu kemudian finishing menggunakan cat duco (gambar 4).

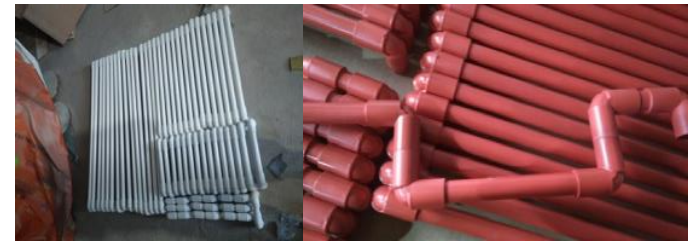

Gambar 4. Proses cat dasar dan finishing pipa PVC

- Membuat pola pada mika rigid sesuai ukuran yang sudah ditentukan sebelumnya.

- Menjahit velcro pada permukaan mika rigid untuk ditempelkan pada saat proses perakitan dengan rangka utama, dan juga menempelkan velcro pada permukaan pipa PVC menggunakan perekat khusus yang disesuaikan dengan karakter material yang digunakan (gambar 5).

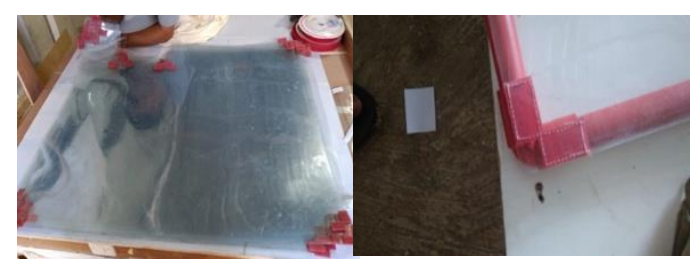

Gambar 5. Proses perekatan velcro pada permukaan mika rigid dan pipa PVC

\section{KESIMPULAN}

Berdasarkan latar belakang perancangan, pandemi Covid-19 di Indonesia berdampak pada terbatasnya segala aktivitas masyarakat, salah satunya adalah bertransaksi. Kegiatan bertransaksi sendiri merupakan kegiatan yang tidak bisa dihindari. Oleh karena itu, pada masa new normal seperti saat ini dibutuhkan fasilitas yang dapat memenuhi kebutuhan pengguna saat melakukan kegiatan tersebut dengan mengikuti protokol kesehatan dan keamanan yang ada agar kegiatan transaksi tetap dapat dilakukan dengan aman dan nyaman tanpa harus khawatir terpapar virus atau kuman. Berdasarkan hal tersebut, perancangan pembatas interaksi ini memiliki simpulan:
- Perancangan pembatas interaksi ini berdasarkan analisis kebutuhan masyarakat terkait kebutuhan untuk melakukan kegiatan transaksi pada masa new normal.

- Perancangan ini juga menggunakan pendekatan metode kualitatif studi kasus dalam upaya memahami kebutuhan pengguna terkait aktivitas transaksi pada masa new normal.

- Perancangan ini bertujuan untuk memenuhi kebutuhan pengguna ketika melakukan kegiatan transaksi dengan aman dan nyaman sekaligus tetap waspada.

- Perancangan ini mempertimbangkan penggunaan bentuk yang sederhana sesuai fungsinya yang mampu membatasi wilayah pengguna satu dan lainnya tanpa membatasi pergerakannya, sesuai dengan pernyataan Radwan \& Morsy (2016) yakni bentuk mendefinisikan material, ukuran, dan fungsi.

- Perancangan ini mempertimbangkan juga penggunaan warna agar dapat memberi suasana dan mempengaruhi mood seseorang secara positif ketika melakukan kegiatan bertransaksi yang aman dan nyaman, sekaligus menjaga pengguna agar tetap waspada. Sesuai dengan pernyataan dari Sanyoto (2005), warna secara fisik adalah sebuah sifat dari cahaya yang dipancarkan, sedangkan secara psikologis sebagai bagian dari pengalaman indera dalam penglihatan.

- Perancangan ini menggunakan material dengan ketentuan ringan dan kokoh serta mudah ditemui di pasaran mengingat dalam keadaan pandemi terdapat keterbatasan distribusi untuk material-material tertentu. Sesuai dengan Palgunadi (2008), perencanaan suatu produk bahan harus mudah ditemui agar memudahkan proses perancangan saat ini maupun di kemudian hari.

- Perancangan ini menggunakan sistem knock down guna memungkinkan untuk dibongkar pasang menyesuaikan kebutuhan, sesuai dengan Palgunadi (2008) bahwa dalam sebuah perancangan bahan yang akan digunakan harus sesuai dengan fungsi yang berbeda antara bagian satu dengan bagian lain dengan fungsi dari masing-masing bagian tersebut saling mempengaruhi antara bagian satu dengan lainnya.

- Pembatas interaksi ini dapat dijadikan rujukan bagi perancangan maupun penelitian produk serupa untuk dapat meminimalkan penyebaran dan penularan virus di masa pandemi. 


\section{DAFTAR PUSTAKA}

Arikunto, S. (2006). Metodologi Penelitian. Yogyakarta: Bina Aksara.

Budiarti, L.N. (2012). Kajian Kemampuan Mengidentifikasi Warna pada Penyandang Gangguan Penglihatan Warna Merah-Hijau (Trichromatic). Jurnal Linguart.

Gill, A., Shah, C. (2012). Determinants of Corporate Cash Holding: Evidence from Canada. International Journal of Economics and Finance, 4(1), 70-79.

Laurens, J.M. (2004). Arsitektur dan Perilaku Manusia. Jakarta: PT. Grasindo.

Motloch, J.L. (1991). Introduction to Landscape Design. New York: Van Nostrand Reinhold.

Mulyadi. (2000). Akutansi Biaya. Yogyakarta: Aditya Media.

Nijdam, N.A. (2010). Mapping Emotion To Color, Human Media interaction. Netherlands: University of Twente.

Palgunadi, Bram. (2008). Disain Produk 3: AspekAspek Desain. Bandung: Penerbit ITB.

Putra, A.R., Nazhar, R.D. (2020). Peranan Material Interior dalam Pengendalian Akustik Auditorium Bandung Creative Hub. Waca Cipta Ruang: Jurnal Ilmiah Desain Interior, 6(2), 71-76.

Radwan, A.H., Morsy, A.A.G. (2016). The Importance of Integrating Street Furniture In The Visual Image Of The City. International Journal of Modern Engineering Research (IJMER), 9(2), 29-53.

Rapoport, Amos. (1969). House Form and Culture. Michigan: Prentice Hall.

Sanyoto, S.E. (2005). Dasar-dasar Tata Rupa \& Desain. Yogyakarta: Arti Bumi Intaran.

Sunaryo, Aryo. (2002). Paparan Perkuliahan Mahasiswa Nirmana 1. Semarang: Jurusan Seni Rupa UNNES.
Wibowo, B.P. (1999). Desain Produk Industri. Bandung: Yayasan Delapan Sepuluh.

Yusup, D.K, dkk. (2020). Pengaruh Bencana Covid19, Pembatasan Sosial, dan Sistem Pemasaran Online Terhadap Perubahan Perilaku Konsumen dalam Membeli Produk Retail. http://digilib.uinsgd.ac.id/id/eprint/30872. (1), 1-10. 